\title{
Pengembangan Media Pembelajaran Berbasis Website (WORDWALL) Mata Pelajaran Fiqih Kelas VII Di Madrasah Tsanawiyah Muhammadiyah 12 Palirangan Untuk Meningkatkan Hasil Belajar Siswa
}

\author{
Idzi' Layyinnati \\ Sekolah Tinggi Ilmu Tarbiyah Muhammadiyah Paciran Lamongan, Indonesia \\ Email: idziela@gmail.com
}

\begin{abstract}
This research has purpose to produces learning materials that proper theoritically and empirically feasible digital learning media in the form of a website (wordwal) supported by increased learning outcomes and student responses to learning with the object of student research in MTs. This study uses a 4D development model (four D models) define, design, develop and disseminate but do not disseminate with a trial design using a one group pretest posttest design implementation. Collecting data using validation methods, questionnaires, tests and observations while data analysis is descriptive qualitative. The results of the study are: Variables related to the validity of the website (wordwal) in terms of feasibility in the theoretical and empirical fields, respectively $82.5 \%$ and 91.3 and very positive student responses $80.3 \%$; assessment of student learning outcomes increased from $\mathrm{N}$-Gain 0.86 with the high category. The media developed is suitable for use in learning and can improve student learning outcomes.
\end{abstract}

KeyWord: Devolopment, Media, Website dan Wordwal

\section{Pendahuluan}

Pendidikan merupakan usaha sadar dan terencana untuk mewujudkan suasana belajar dan proses pembelajaran agar peserta didik secara aktif mengembangkan potensi diri untuk mengikuti perkembangan zaman yang menuntut tiap individu mampu bersaing dalam bidang ilmu pengetahuan dan teknologi (IPTEK). Salah satu usahanya adalah dengan mengembangkan kekreatifan guru dalam proses pembelajaran. Proses pembelajaran merupakan usaha dalam meningkatkan kualitas pendidikan agar dapat mengimbangi dan mengikuti perkembangan IPTEK.

Pendidikan merupakan aspek yang terpenting untuk pembangunan Negara sebagai upaya meningkatkan sumber daya manusia dan investasi bangsa. Menurut Mulyasa (2010), ada beberapa aspek yang perlu ditekankan untuk meningkatkan kualitas pembelajaran. Aspek tersebut mencakup peningkatan aktivitas dan kreativitas peserta didik, serta peningkatan motivasi belajar.

Pembelajaran merupakan transfer ilmu antara guru dan murid, sehingga proses pembelajaran harus berupa pengetahuan yang utuh dan bermakna. Suatu proses pembelajaran agar bermakna dan pengetahuan yang utuh sampai pada siswa dengan baik dan benar, maka diperlukan suatu perantara berupa media yang dapat membantu siswa 


\section{Idzi’ Layyinnati}

mempermudah proses transfer ilmu dari guru terhadap siswa. Hamalik (2005) menyatakan bahwa "media pembelajaran adalah alat, metode dan teknik yang digunakan dalam rangka lebih mengefektifkan komunikasi dan interaksi antara guru dan siswa dalam proses pembelajaran dikelasnya". Media pembelajaran menurut adalah media yang membawa pesan atau informasi dengan tujuan instruksional atau mengandung maksud-maksud pengajaran(Heinich 1996).

Perkembangan pesat dalam teknologi dapat mengarah pada pembetukan lingkungan yang kompetitif, dan kondisi kompetitif ini dapat dimanfaatkan melalui media pembelajaran interaktif berbasis permainan (game). gamifikasi pembelajaran dapat meningkatkan minat peserta didik pada pelajaran, dan mendorong peserta didik untuk menjadi lebih ambisius dan lebih bergairah dalam belajar, dengan gamifikasi Mereka dapat melihat status pencapaian mereka dan meningkatkan diri mereka.

Berdasarkan hasil observasi yang dilakukan peneliti di MTs. Muhammadiyah 12 Palirangan, peserta didik kelas VII memiliki karakteristik yang cenderung aktif dan sebagian besar telah menggunakan smartphone sebagai media bermain dirumah. Hal tersebut menjadikan daya tarik peserta didik terhadap pembelajaran akan kurang jika guru kurang kreatif dan inovatif dalam mengelola kelas tersebut, terlebih pada mata pelajaran yang dianggap membosankan.

Mata pelajaran Fiqih merupakan salah satu komponen Pendidikan Agama Islam di sekola menengah. Menurut peserta didik, guru mata pelajaran Fiqih masih selalu menggunakan metode konvensional atau metode lama khususnya metode ceramah dan hampir tidak pernah menggunakan media dalam proses pembelajaran. Hal tersebut menjadikan mata pelajaran Fiqih dianggap sebagai pelajaran yang membosankan, sehingga motivasi peserta didik dalam mengikuti pelajaran tersebut menjadi kurang dan tidak memiliki ambisi untuk belajar dengan sungguh-sungguh. Rendahnya hasil belajar peserta didik pada mata pelajaran Fiqih menjadi tanda bahwa motivasi dan pemahaman peserta didik dalam menerima materi masih kurang.

Pendidik dituntut untuk berkreasi memanfaatkan segala media pembelajaran yang Anda agar para peserta didik tidak cepat jenuh menerima pembelajaran. Lebih-lebih di era pandemi seperti ini, pendidik harus kreatif dalam menyuguhkan pembelajarannya. Salah satu aplikasi yang dapat digunakan untuk membuat media pembelajaran yang interaktif adalah wordwall. 
Aplikasi wordwall ini menjadikan proses pembelajaran menjadi menyenangkan dan tidak membosankan bagi peserta didik maupun bagi pendidik karena aplikasi wordwall menekankan gaya belajar lebih rileks terhadap pembelajaran yang sedang atau telah dipelajarinya.

Aplikasi berbasis website ini dapat digunakan untuk membuat media pembelajaran seperti kuis, mencocokkan, memasangkan pasangan, anagram, acak kata, pencarian kata, mengelompokkan dan lain sebagainya. Menariknya lagi, selain pengguna dapat menyediakan akses media yang telah dibuatnya melalui daring, juga dapat diunduh dan dicetak pada kertas. Aplikasi ini menyediakan 18 template yang dapat diakses secara gratis serta pengguna dapat berganti template aktivitas satu ke aktivitas lainnya dengan mudah. Guru juga dapat menjadikan konten buatannya sebagai tugas.

Dalam aplikasi perolehan skor setiap peserta didik ditentukan oleh kecepatan dan ketepatan mereka dalam menjawab kuis. Semakin cepat dalam menjawab kuis, maka semakin tinggi skor yang didapatkan. Selain itu, guru dapat menentukan batasan waktu maksimal untuk menjawab setiap butir kuisnya. Guru juga dapat mengunduh hasil dari kuis yang dikerjakan peserta didik sehingga hasil tersebut dapat diolah dan dianalisis dengan mudah

Latar belakang yang telah diuraikan di atas maka kami melakukan penelitian dengan judul : "Pengembangan Media Pembelajaran Berbasis Website (wordwall) Mata Pelajaran Fiqih Kelas VII di MTs. Muhammadiyah 12 Palirangan Untuk Meningkatkan Hasil Belajar Siswa”.

\section{Rumusan Masalah}

Adapun penjabaran dari rumusan masalah di atas adalah sebagai berikut:

1. Bagaimana kelayakan media pembelajaran berbasis website (wordwall) ditinjau berdasarkan:

a. Kriteria komponen kelayakan materi

b. Kriteria komponen penyajian

c. Kriteria komponen kebahasaan

2. Bagaimana kelayakan media pembelajaran berbasis website (wordwall) ditinjau berdasarkan Respons Siswa? 


\section{Kajian Teori}

\section{A. Media Pembelajaran}

\section{Pengertian Media Pembelajaran}

Pengertian Media Pembelajaran Kata media berasal dari bahasa Latin medius yang secara harfiah berarti tengah, perantara atau pengantar. Dalam bahasa Arab, media adalah perantara atau pengantar pesan dari pengirim kepada penerima pesan. Media adalah pengantar pesan dari pengirim ke penerima pesan, dengan demikian media merupakan wahana penyalur informasi belajar atau penyalur pesan. Berdasarkan Asosiasi Pendidikan Nasional (National Education Association/NEA) memiliki pengertian yang berbeda. Media adalah bentuk-bentuk komunikasi baik tercetak maupun audiovisual serta peralatannya. Media hendaknya dapat dimanipulasi, dapat dilihat, didengar dan dibaca.

Media pembelajaran merupakan suatu teknologi pembawa pesan yang dapat digunakan untuk keperluan pembelajaran, media pembelajaran merupakan sarana fisik untuk menyampaikan materi pelajaran. Media pembelajaran merupakan sarana komunikasi dalam bentuk cetak maupun pandang dan dengar termasuk teknologi perangkat keras.

\section{Fungsi Media Pembelajaran}

Dua unsur yang sangat penting dalam kegiatan pembelajaran, yaitu metode dan media pembelajaran. Kedua hal ini saling berkaitan satu sama lain. Pemilihan suatu metode akan menentukan media pembelajaran yang akan dipergunakan dalam pembelajaran tersebut Dalam proses pembelajaran, media memiliki kontribusi dalam meningkatkan mutu dan kualitas pembelajaran. Kehadiran media tidak saja membantu pendidik dalam menyampaikan materi ajarnya, tetapi memberikan nilai tambah kepada kegiatan pembelajaran.

\section{Manfaat Media Pembelajaran}

Sudjana dan Rivai mengemukakan manfaat media pembelajaran dalam proses belajar peserta didik, yaitu:

a. Pembelajaran akan lebih menarik perhatian peserta didik sehingga dapat menumbuhkan motivasi belajar 
b. Bahan pembelajaran akan lebih jelas maknanya sehingga dapat lebih dipahami oleh peserta didik dan memungkinkannya menguasai dan mencapai tujuan pembelajaran.

c. Metode mengajar akan lebih bervariasi, tidak semata-mata komunikasi verbal melalui penuturan kata-kata oleh pendidik, sehingga peserta didik tidak bosan dan pendidik tidak kehabisan tenaga, apalagi kalau pendidik mengajar pada setiap jam pelajaran.

Peserta didik dapat lebih banyak melakukan kegiatan belajar sebab tidak hanya mendengarkan uraian pendidik, tetapi juga aktivitas lain seperti mengamati, melakukan, mendemonstrasikan, memerankan, dan lain-lain.

\section{B. Word Wall}

\section{Pengertian Wordwall}

Wordwall adalah sebuah aplikasi yang menarik pada browser. Aplikasi ini khusus bertujuan sebagai sumber belajar, media, dan alat penilaian yangm menyenangkan bagi murid. Di dalam halaman wordwall juga disediakan contohcontoh hasil kreasi guru sehingga pengguna baru mendandapatkan gambaran akan berkreasi seperti apa. Wordwall dapat diartikan web aplikasi yang kita gunakan untuk membuat games berbasis kuis menyenangkan. Web aplikasi ini cocok buat merancang dan mereview sebuah penilaian pembelajaran,

\section{Pembelajaran Fiqih}

\section{Pengertian Pembelajaran Fiqih}

Mata pelajaran Fiqih dalam adalah salah satu bagian mata pelajaran Pendidikan Agama Islam yang diarahkan untuk menyiapkan peserta didik untuk mengenal memahami,menghayati dan mengamalkan hukum Islam yang kemudian menjadi dasar pandangan hidupnya (way of life) melalui Kegiatan bimbingan, pengajaran,latihan penggunaan, pengamalan dan pembiasaan.

Pembelajaran fiqih di bertujuan untuk membekali peserta didik agar dapat:

a. mengetahui dan memahami pokok-pokok hukum Islam dalam mengatur ketentuan dan tata cara menjalankan hubungan manusia dengan Allah yang diatur dalam fiqih ibadah dan hubungan manusia dengan sesama yang diatur dalam fiqih muamalah.

b. Melaksanakan dan mengamalkan ketentuan hukum Islam dengan benar dalam melaksanakan ibadah kepada Allah dan ibadah sosial. Pengalaman tersebut 


\section{Idzi’ Layyinnati}

diharapkan menumbuhkan ketaatan menjalankan hukum Islam, disiplin dan tanggung jawab sosial yang tinggi dalam kehidupan pribadi maupun sosial.

Pembelajaran fiqih pada hakikatnya adalah proses komunikasi yakni proses penyampaian pesan pelajaran fiqih dari sumber pesan atau pengirim atau guru melalui saluran atau media tertentu kepada penerima pesan (siswa). Adapun pesan yang akan dikomunikasikan dalam mengetahui dan memahami pokok-pokok hukum Islam dalam mengatur ketentuan dan tata cara menjalankan hubungan manusia dengan Allah yang di atur dalam fiqih ibadah dan hubungan manusia dengan sesama yang diatur dalam Fiqih Muamalah.

\section{Metode Penelitian}

\section{A. Model penelitian}

Model pengembangan 4-D (four D Models) terdiri dari 4 tahap yaitu Define, Design, Develop dan Disseminate atau dikenal dengan 4-D, yaitu pendefinisian, perancangan, pengembangan, dan penyebaran. Model ini dikembangkan oleh Thiagarajan, dkk (1974).

\section{B. Jenis penelitian}

Penelitian ini merupakan jenis penelitian non eksperiment yaitu Descriptive Research yaitu penelitian pengembangan yang mengacu pada model 4-D (Diadaptasi Thiagarajan 1974). Media yang digunakan adalah media Wordwall yang dikembangkan berdasarkan aplikasi dengan pembelajaran PAI mata pelajaran fiqih.

\section{Sasaran penelitian}

Sasaran penelitian ini adalah media pembelajaran berbasis website (wordwall) mata pelajaran fiqih.

\section{Rancangan penelitian}

Penelitian ini mengacu pada model 4D yang dikemukakan oleh Thiagarajan. Model 4D terdiri dari 4 tahap, yaitu pendefinisian (Define), perancangan (Design), pengembangan (Develop), dan penyebaran (Disseminate). Pada penelitian ini hanya dibatasi pada tahap pengembangan dan uji kelayakan secara terbatas.

\section{E. Metode pengumpulan data}

Penelitian ini metode yang digunakan untuk mengumpulkan data yaitu menggunakan lembar angket, metode test, dan lembar observasi. Metode lembar angket berupa angket validasi dan angket respon siswa. Tujuan dari lembar angket ini adalah 
untuk mengetahui penilaian dan pendapat ahli, guru PAI, dan siswa MTs. Muhammadiyah 12 Palirangan terhadap media pembelajaran berbasis website (wordwall) mata pelajaran fiqih yang dikembangkan. Metode Test berupa hasil belajar yang dikerjakan oleh siswa untuk mengetahui hasil pemahaman konsep yang diterima oleh siswa melalui pembelajaran menggunakan media pembelajaran berbasis website (wordwall) mata pelajaran fiqih hal tersebut dilihat pada ketuntasan belajar siswa. Metode observasi digunakan untuk mengetahui kegiatan siswa selama menggunakan media pembelajaran berbasis website (wordwall) mata pelajaran fiqih yang dikembangkan. Hasil observasi dan hasil belajar digunakan untuk mendukung data yang diperoleh dan tidak mempengaruhi hasil kelayakan media pembelajaran berbasis website (wordwall) mata pelajaran fiqih..

\section{F. instrumen penelitian}

Instrumen penelitian yang digunakan dalam penelitian ini berjumlah 5 instrumen yaitu:

\section{Lembar Telaah}

Lembar telaah adalah lembar yang digunakan untuk memperoleh masukan dari para ahli materi dan ahli bahasa tentang media pembelajaran berbasis website (wordwall) mata pelajaran fiqih yang dikembangkan, sehingga dapat diperoleh Media yang layak menurut ahli

2. Lembar Validasi

Lembar validasi adalah lembar yang digunakan untuk menilai website (wordwall) yang dikembangkan dari segi kelayakan materi, penyajian dan kebahasaan. Hasil dari validasi inilah yang nantinya akan menentukan kelayakan dari media pembelajaran berbasis website (wordwall) mata pelajaran fiqih berdasarkan penilaian dari 2 dosen, 1 dosen bahasa indonesia dan 1 guru PAI.

3. Lembar Respon Siswa

Lembar respon siswa ini ditujukan pada 1 kelas yang terdiri dari 20 siswa kelas VII MTs. Muhammadiyah 12 Palirangan. Untuk mengetahui respons mereka terhadap website (wordwall) yang dikembangkan, yang meliputi materi/isi, penampilan penyajian, dan kebahasaan.

4. Tes Hasil Belajar

Tes hasil belajar digunakan untuk mengetahui penguasaan konsep subjek peneliti terhadap materi yang disampaikan setelah menggunakan website (wordwall) 


\section{Idzi’ Layyinnati}

dan ketercapaian tujuan pembelajaran yang dikembangkan, penguasaan konsep dilihat dari ketuntasan hasil belajar. Tes hasil belajar ini disajikan di ahir website (wordwall) dalam bentuk game yang terdiri dari 25 soal yang telah divalidasi oleh ahli materi dan guru PAI.

5. Lembar Observasi

Berisi tentang kegiatan siswa selama menggunakan media pembelajaran berbasis website (wordwall) mata pelajaran fiqih. Lembar observasi mencatat aktivitas siswa saat uji coba terbatas media pembelajaran berbasis website (wordwall) mata pelajaran fiqih.

\section{G. Metode analisis data}

Metode analisis data hasil dari uji kelayakan yang digunakan pada penelitian ini sebagai berikut:

1. Analisis Data Hasi Validasi

Analisis data hasil validasi dilakukan dengan menggunakan metode diskriptif kuantitatif yang menggunakan persentase. Persentase diperoleh dengan membandingkan skor hasil pengumpulan data dari seluruh validator dengan skor kriteria. Analisis ini dilakukan dengan menggunakan perhitungan skala likert menurut Riduwan pada Tabel 1 berikut:

Tabel 1

Kriteria Skor Skala Likert

\begin{tabular}{|l|l|}
\hline Penilaian & Nilai/skor \\
\hline Sangat baik & 4 \\
\hline Baik & 3 \\
\hline Cukup & 2 \\
\hline Kurang & 1 \\
\hline
\end{tabular}

(Diadaptasi Riduwan, 2010)

Rumus yang digunakan untuk memperoleh persentase sebagai berikut:

$$
K=\frac{F}{N x I x R} x 100 \%
$$

Keterangan:

$\mathrm{K}=$ Persentase kelayakan

$\mathrm{F}=$ Jumlah keseluruhan jawaban responden

$\mathrm{N}=$ Skor tertinggi dalam angket

$\mathrm{I}=$ Jumlah pertanyaan dalam angket

$\mathrm{R}=$ Jumlah penilai (Riduwan, 2010) 
Hasil analisis data validasi digunakan untuk mengetahui kelayakan media pembelajaran berbasis website (wordwall) mata pelajaran fiqih dengan menggunakan interpretasi skor sebagai berikut:

Tabel 2

Interpretasi Skor Penilaian Guru PAI SMP/MTs

\begin{tabular}{|l|l|}
\hline Persentase & Kriteria \\
\hline $20 \%-40 \%$ & Kurang \\
\hline $41 \%-60 \%$ & Cukup \\
\hline $61 \%-80 \%$ & Baik / layak \\
\hline $81 \%-100 \%$ & Sangat baik / sangat layak \\
\hline
\end{tabular}

(Diadaptasi Riduwan, 2010)

Media pembelajaran berbasis website (wordwall) mata pelajaran fiqih dikatakan layak apabila semua aspek dalam angket mendapat persentase sebesar $\geq 61 \%$ dengan kriteria layak dan sangat layak.

2. Analisis Data Hasil Angket Respons Siswa

Analisis data hasil angket respons siswa berisi butir-butir penilaian terhadap media website (wordwall) yang dikembangkan. Angket respons siswa dianalisis dengan menggunakan metode deskriptif kuantitatif dengan menggunakan persentase. Angket respons siswa disusun berdasarkan skala Guttman yang dinyatakan dalam bentuk pernyataan. Angket yang telah diisi dihitung berdasarkan kriteria skala pada Tabel 3 berikut:

\section{Tabel 3}

Kriteria Skor Guttman

\begin{tabular}{|l|l|}
\hline Jawaban & Nilai/Skor \\
\hline Ya & 1 \\
\hline Tidak & 0 \\
\hline
\end{tabular}

(Riduwan, 2010)

Untuk mengetahui respons siswa tentang format, kualitas dan ketertarikan siswa terhadap media pembelajaran berbasis website (wordwall) mata pelajaran fiqih digunakan rumus:

$$
K=\frac{F}{N x I x R} x 100 \%
$$

Keterangan:

$\mathrm{K}=$ Persentase kelayakan

$\mathrm{F}=$ Jumlah keseluruhan jawaban responden

$\mathrm{N}=$ Skor tertinggi dalam angket

$\mathrm{I}=$ Jumlah pertanyaan dalam angket

$\mathrm{R}=$ Jumlah penilai (Riduwan, 2010). 
Kriteria respons dari siswa dinyatakan kuat apabila mendapat persentasi sebesar $\geq 61 \%$ dengan kreteria sebagaimana Tabel 4

Tabel 4

Interpretasi Skor Respons Siswa

\begin{tabular}{|c|c|}
\hline Persentase & Kriteria \\
\hline $21,00 \%-40,99 \%$ & Kurang \\
\hline $41,00 \%-60,99 \%$ & Cukup \\
\hline $61,00 \%-80,99 \%$ & Baik / layak \\
\hline $81,00 \%-100,00 \%$ & Sangat baik / sangat layak \\
\hline
\end{tabular}

(Diadaptasi Riduwan, 2010)

3. Analisis Data Tes Hasil Belajar

Analisis hasil belajar siswa digunakan untuk mengetahui persentase pencapaian ketuntasan siswa, baik ketuntasan individu maupun klasikal. Pencapaian ketuntasan siswa dapat dihitung dengan rumus:

$$
\text { Ketuntasan siswa individual }=\frac{\text { jumlah scor yang diperoleh siswa }}{\text { jumlah skor maksimal }} \times 100
$$

Siswa dinyatakan tuntas dalam pembelajaran jika mencapai nilai ketuntasan $\geq$ 70. Ketuntasan tujuan pembelajaran secara klasikal dinyatakan tercapai jika mencapai persentase $\geq 70 \%$ siswa dalam 1 kelas tuntas. adapun rumus yang digunakan untuk menentukan ketuntasan klasikal, yaitu:

$$
\text { Ketuntasan siswa klasikal }=\frac{\text { jumlah scor yang nilainya mencapi KKM }}{\text { jumlah skor maksimal }} \times 100
$$

4. Analisis Data Hasil Observasi

Berisi tentang kegiatan siswa selama menggunakan media media pembelajaran berbasis website (wordwall) mata pelajaran fiqih. Lembar observasi mencatat aktivitas siswa saat uji coba terbatas media website (wordwall).

\section{Hasil Penelitian dan Pembahasan}

\section{A. Hasil penelitian}

1. Tahap Pendefinisian (Define) 
Tujuan tahap ini adalah menetapkan dan mendefiniskan syarat-syarat pembelajaran. Langkah-langkah tahap ini adalah analisis ujung depan, analisis siswa, analisis tugas, analisis konsep, dan perumusan indikator pembelajaran.

a. Analisis ujung depan

Hal yang perlu diperhatikan dalam tahap ini adalah kurikulum yang berlaku, teori belajar yang relevan, ketrampilan proses dan tututan masa depan. Kurikulum yang berlaku saat ini adalah kurikulum 2013 (K13). Pengajaran dalam K13 dituntut untuk pembelajaran yang berorentasi pada siswa yaitu siswa harus berperan aktif dalam kegiatan pembelajaran, sedangkan posisi guru adalah sebagai fasilitator.

Rata-rata usia siswa kelas VII MTs. Muhammadiyah 12 Palirangan adalah 12-13 tahun. Menurut Piaget, usia tersebut termasuk dalam tahap operasi formal. Tahap operasi formal adalah tahap dimana anak sudah berfikir secara abstrak dalam menghadapi situasi dan penalaran hipotesis (Hergenhahn. dkk, 2009). Selain itu siswa di sekolah MTs. Muhammadiyah 12 Palirangan juga telah dapat mengoperasikan computer/HP secara aktif sehingga penggunaan media website (wordwall) sangat menarik bagi siswa.

b. Analisis tugas

Pada tahap ini dilakukan identifikasi materi dan identifikasi prosedur penyelesaian tugas dengan menentukn materi apa yang dibuat dan dimasukan dalam game media website (wordwall) .

c. Analisis konsep

Langkah yang dilakukan adalah mengidentifikasi konsep yang akan disampaikan dan penyusunan soal yang dapat didukung dengan berbagaimacam bentuk game dan bentuk soal dalam proses dan Perumusan tujuan pembelajaran.

\section{Tahap Perancangan (Design)}

Tahap perancangan bertujuan untuk mendesain format media yang akan dikembangkan, penjabaran materi yang akan dibahas dalam website (wordwall), langkah kerja percobaan, latihan soal, dan evaluasi. Pada tahap ini terdiri dari dua tahapan yaitu tahap disain dan tahap pembuatan.

Untuk pembuat game quiz bagi pendidik atau trainer: 
a. Buka Wordwall melalui browser Mozila, Goggle Chrome atau Uc browser lalu Klik tautan Wordwall.net.

b. Setelah klik tautan Wordwall.net, lalu akan muncul tampilan seperti ini. Pilih Sign Up To Start Creating untuk daftar Jika belum punya akun.

c. Setelah daftar dan telah mendapatkan konfirmasi email dari Wordwall akan muncul 18 game permainan yang di tawarkan, Pilih salah satu game yang di inginkan. Sebagai contoh peneliti memilih game Match up.

d. Pilih Layout game yang kita suka, saya coba memilih design layout berwarna coklat.

e. Akan muncul tampilan seperti ini pada dashboard, lalu scrool ke bawah untuk mengedit permai

f. Edit game sesuai kebutuhan mulai dari tema game, waktu quiz dan lain

g. Jika sudah selesai membuat project lalu bias share ke peserta didik

h. Maka akan muncul layar seperti ini, klik set assignme

i. Setting nama judul pemainan, lalu pilih apakah peserta didik harus menyertakan nama dan setting waktu yang dimana ada batasan waktu dalam memainkan game tersebut, yang terakhir diakhir permainan ada opsi pilihan pengaturan apakah jawaban, leaderboard dan start again di munculkan dalam game.

j. Klik start lalu bagikan link kepada peserta didik.

k. Klik my result untuk melihat data statistik nilai skor untuk peserta didik

3. Tahap pengembangan (Develop).

Berdasarkan tahapan 4D, tahapan pengembangan terdiri dari 4 tahapan yaitu telaah, revisi, validasi kelayakan website (wordwall), dan uji coba terbatas. Keempat tahapan tersebut dijelaskan sebagai berikut:

a. Telaah

Tujuan dari tahap telaah adalah untuk menyempurnakan draf 1 website (wordwall) yang telah dibuat. Telaah dilakukan oleh 2 orang ahli materi yaitu Drs. H. Mohammad Hasan Rasidi, M.Pd.I (Dosen PAI Sekolah Tinggi Ilmu Tarbiyah Muhammadiyah Paciran) dan H. Muh. Rifqi Rosyidi, Lc, M.Ag (Dosen PAI Sekolah Tinggi Ilmu Tarbiyah Muhammadiyah Paciran), serta 1 orang ahli bahasa indonesia yaitu Maftuhah, M.Pd (Dosen Bahasa Indonesia Sekolah Tinggi Ilmu Tarbiyah Muhammadiyah Paciran). 
b. Revisi

Setelah melakukan tahap 1 yaitu telaah website (wordwall) draf 1 dan mendapat saran dari ahli materi dan ahli bahasa untuk perbaikan LKS yang dikembangkan maka langkah selanjutnya yaitu merevisi website (wordwall) sesuai dengan saran yang telah diberikan ahli bahasa dan ahli materi. Sehingga, diperoleh website (wordwall) draf II. Hasil draf I yang telah ditelaah dan direvisi.

c. Validasi Kelayakan website (wordwall)

Pada tahap ini, website (wordwall) draf I yang telah direvisi menjadi daraf II dinilai oleh 2 orang dosen ahli materi yaitu Drs. H. Mohammad Hasan Rasidi, M.Pd.I (Dosen PAI Sekolah Tinggi Ilmu Tarbiyah Muhammadiyah Paciran) dan H. Muh. Rifqi Rosyidi, Lc, M.Ag (Dosen PAI Sekolah Tinggi Ilmu Tarbiyah Muhammadiyah Paciran), dan 1 guru PAI yaitu Muslim S.Pd. (guru PAI MTs. Muhammadiyah 12 Palirangan), serta 1 orang ahli bahasa indonesia yaitu Maftuhah, M.Pd (Dosen Bahasa Indonesia Sekolah Tinggi Ilmu Tarbiyah Muhammadiyah Paciran).

Hasil penilaian media media pembelajaran berbasis website (wordwall) mata pelajaran fiqih pada Tabel 5 sebagai berikut:

\section{Tabel 5 Data Hasil Penilaian Ahli Materi dan Ahli Bahasa Media Pembelajaran Berbasis Website (Wordwall) Mata Pelajaran Fiqih.}

No Aspek yang divalidasi Persentasi Kategori

Kelayakan Materi Media Media Pembelajaran Berbasis Website (wordwall) Mata Pelajaran Fiqih

1. Materi pokok media media 91.66 Sangat Layak pembelajaran berbasis website (wordwall) mata pelajaran fiqih ai dengan indikator.

2. Materi pokok media media pembelajaran berbasis website

91.66 Sangat Layak (wordwall) mata pelajaran fiqih.

3. Quis yang dimasukan dalam 75.00 Layak game sesuai dengan materi dan KD yang dikembangkan.

4. Mengaitkan dengan $\quad 91.66$ permasalahan kehidupan nyata. 
No Aspek yang divalidasi

5. media media pembelajaran berbasis website (wordwall) mata pelajaran fiqih yang disajikan sesuai dengan kebenaran fakta, konsep, prinsip dan teori lensa mata serta tidak menimbulkan banyak penafsiran.

\% Tampilan Kelayakan Materi Media Media Pembelajaran Berbasis Website (wordwall) Mata Pelajaran

Fiqih

Kelayakan Media Pembelajaran Berbasis Website (wordwall) Mata Pelajaran Fiqih

1. Memuat soal yang inovatif . $\quad 91.66$

2. Sisww diajak berfikir kreatif 91.66 dengan penggunaan website .

3. Tata letak teks, gambar, tabel, dan grafik serta warna disajikan secara serasi.

\% Tampilan Kelayakan Penyajian Media Media Pembelajaran Berbasis Website (wordwall) Mata Pelajaran Fiqih

Kriteria Kelayakan Bahasa Media Media Pembelajaran Berbasis Website (wordwall) Mata Pelajaran Fiqih

1. Bahasa yang digunakan sesuai 93.75

Sangat Layak dengan perkembangan peserta didik.

2. Tata bahasa dan ejaan sesuai dengan Ejaan Yang Disempurnakan (EYD).

3. Kebakuan penggunaan istilah 93.75 dan simbol.

4. Penggunaan bahasa dapat 81.25 menyampaikan pesan.
Persentasi Kategori

Sangat Layak

Sangat Layak

Sangat Layak

Sangat Layak

Sangat Layak

Sangat Layak 
No Aspek yang divalidasi

5. Keutuhan makna dalam penyampaian soal dan pemilihan jawaban

\section{\% Tampilan Kriteria Kelayakan Bahasa Media Media Pembelajaran Berbasis Website (wordwall) Mata Pelajaran Fiqih}

Persentasi

$(\%)$

Penjabaran dari penilaian di atas adalah sebagai berikut:

1) Kelayakan materi media media pembelajaran berbasis website (wordwall) mata pelajaran fiqih

Dari perhitungan 5 kriteria kelayakan materi yang telah divalidasi untuk menentukan kelayakan website (wordwall) menunjukkan bahwa media media pembelajaran berbasis website (wordwall) mata pelajaran fiqih yang dikembangkan telah memenuhu syarat kriteria kelayakan materi LKS dengan persentase rata-rata sebesar $88.88 \%$ yang termasuk dalam katagori sangat layak.

2) Kelayakan Penyajian media media pembelajaran berbasis website (wordwall) mata pelajaran fiqih

Dari perhitungan ketiga kriteria kelayakan penyajian media media pembelajaran berbasis website (wordwall) mata pelajaran fiqih menunjukan bahwa LKS yang dikembangkan telah memenuhi syarat kriteria kelayakan penyajian dengan persentase rata-rata sebesar $88.88 \%$ yang termasuk dalam kategori sangat layak.

3) Kelayakan Penyajian media media pembelajaran berbasis website (wordwall) mata pelajaran fiqih

Dari perhitungan kriteria kelayakan penyajian pembelajaran website (wordwall) menunjukan bahwa website (wordwall) yang dikembangkan telah memenuhi syarat kriteria kelayakan penyajian pembelajaran dengan persentase rata-rata sebesar $92.85 \%$ yang termasuk dalam kategori sangat layak.

4) Kriteria Kelayakan media media pembelajaran berbasis website (wordwall) mata pelajaran fiqih. 
Dari perhitungan kelima kriteria kelayakan bahasa website (wordwall) menunjukan bahwa website (wordwall) yang dikembangkan telah memenuhi syarat kriteria kelayakan bahasa dengan persentase rata-rata sebesar $85.00 \%$ yang termasuk dalam kategori sangat layak.

d. Uji Coba Terbatas

Berikut ini adalah hasil respons siswa setelah menggunakan website (wordwall).

\section{Tabel 6 Data Hasil Respons Siswa Terhadap Media Media Pembelajaran Berbasis}

No Website (wordwall) Mata Pelajaran Fiqih

Aspek yang dinilai Persentase

Kategori

$$
\%
$$

Kriteria materi Media Media Pembelajaran Berbasis Website (wordwall)

Mata Pelajaran Fiqih

1. Apakah media media pembelajaran

94.73 Sangat Layak

berbasis website (wordwall) mata

pelajaran fiqih membantu anda untuk

memahamiyang disampaikan?

2. Apakah media pembelajaran berbasis website (wordwall) mata pelajaran

$94.73 \quad$ Sangat Layak

fiqih memotivasi anda dalam pembelajaran?

3. Apakah media media pembelajaran berbasis website (wordwall) mata pelajaran fiqih mudah dipahami?

4.

Apakah anda senang dengan pembelajaran menggunakan computer/hp media media pembelajaran berbasis website (wordwall) mata pelajaran fiqih?

\% Kriteria Media Pembelajaran 93.42 Sangat Layak Berbasis Website (wordwall) Mata $94.73 \quad$ Sangat Layak Pelajaran Fiqih

Kriteria kebahasaan Media Pembelajaran Berbasis Website (wordwall) Mata Pelajaran Fiqih

9. Apakah media media pembelajaran 73.68 Layak berbasis website (wordwall) mata pelajaran fiqih menggunakan bahasa indonesia yang baik dan benar? 
10. Apakah anda paham dengan soal yang terdapat dalam media media pembelajaran berbasis website (wordwall) mata pelajaran fiqih?

11. Apakah bahasa yang digunakan sudah komunikatif?

89.47 Sangat Layak

Analisis data dari hasil penelitian dijabarkan sebagai berikut:

1) Kriteria materi media pembelajaran berbasis website (wordwall) mata pelajaran fiqih Berdasarkan pada Tabel 6 di atas telah didapatkan pendapat siswa tentang website (wordwall) yang digunakan dalam pembelajaran memperoleh persentase rata-rata sebesar $93.42 \%$ dengan kategori sangat layak.

2) Kriteria kebahasaan media pembelajaran berbasis website (wordwall) mata pelajaran fiqih

Berdasarkan pada Tabel 6 di atas telah didapatkan pendapat siswa tentang website (wordwall) yang digunakan dari aspek kebahasaan memperoleh persentase sebesar $75.43 \%$ dengan kategori layak.

e. Data tes hasil belajar

Media yang baik maka harus bermanfaat bagi siswa, yaitu membantu siswa dalam pemahaman konsep atau menguasai materi dan ketercapaian seluruh tujuan pembelajaran yang diharapkan dengan mencapai kriteria ketuntasan minimum $(\mathrm{KKM})$ yang ditetapkan sekolah sebesar $\geq 70$. Hal tersebut dapat diketahui dari tes hasil belajar siswa menggunakan media website (wordwall) yang telah dikembangkan. Data hasil tes ditampilkan pada Tabel 7

Tabel 7 Data Tes Hasil Belajar Media Pembelajaran Berbasis Website (wordwall) Mata Pelajaran Fiqih

$\begin{array}{lllll}\text { No } & \begin{array}{l}\text { Nama } \\ \text { siswa }\end{array} & \text { Nilai } & \begin{array}{l}\text { Ketuntasa } \\ \text { n } \\ \text { individual }\end{array} & \begin{array}{l}\text { Kategor } \\ \text { i }\end{array} \\ \text { 1. } & \text { A } & 71 & 70 & \text { Tuntas } \\ \text { 2. } & \text { B } & 84 & 70 & \text { Tuntas }\end{array}$




$\begin{array}{lllll}\text { No } & \begin{array}{l}\text { Nama } \\ \text { siswa }\end{array} & \text { Nilai } & \begin{array}{l}\text { Ketuntasa } \\ \text { n } \\ \text { individual }\end{array} & \begin{array}{l}\text { Kategor } \\ \text { i }\end{array} \\ \text { 3. } & \text { C } & 85 & 70 & \text { Tuntas } \\ \text { 4. } & \text { D } & 82 & 70 & \text { Tuntas } \\ \text { 5. } & \text { E } & 77 & 70 & \text { Tuntas } \\ \text { 6. } & \text { F } & 83 & 70 & \text { Tuntas } \\ \text { 7. } & \text { G } & 76 & 70 & \text { Tuntas } \\ \text { 8. } & \text { H } & 85 & 70 & \text { Tuntas } \\ \text { 9. } & \text { I } & 73 & 70 & \text { Tuntas } \\ \text { 10. } & \text { J } & 85 & 70 & \text { Tuntas } \\ \text { 11. } & \text { K } & 86 & 70 & \text { Tuntas } \\ \text { 12. } & \text { L } & 76 & 70 & \text { Tuntas } \\ \text { 13. } & \text { M } & 87 & 70 & \text { Tuntas } \\ \text { 14. } & \text { N } & 85 & 70 & \text { Tuntas } \\ \text { 15. } & \text { O } & 73 & 70 & \text { Tuntas } \\ \text { 16. } & \text { P } & 85 & 70 & \text { Tuntas } \\ \text { 17. } & \text { Q } & 88 & 70 & \text { Tuntas } \\ \text { 18. } & \text { R } & 80 & 70 & \text { Tuntas } \\ \text { 19. } & \text { S. } & 71 & 70 & \text { Tuntas } \\ \text { 20 } & \text { T } & 75 & 70 & \text { Tuntas } \\ \text { Ketuntasan Klasikal } & \mathbf{1 0 0 \%} & \text { Tuntas }\end{array}$

Berdasarkan data hasil tes pada Tabel 7 di atas terdapat 2 siswa yang yang standar ketuntasasan hanya sedikit melampai KKM yaitu dengan skor 71, hal tersebut dikarenakan siswa tersebut kurang fokus dalam pembelajaran dan hasil dari evaluasi yang siswa dapatkan melampaui KKM. Informasi tersebut didapatkan dari observer yang mengatakan bahwa siswa tersebut kurang teliti dalam memahami soal pada saat pertemuan kedua.

Secara individual seluruh siswa tuntas $100 \%$ dan secara klasikal dapat tercapai dengan persentase sebesar 100\% yang artinya Media Pembelajaran 
Berbasis Website (wordwall) Mata Pelajaran Fiqih layak digunakan dalam pembelajaran.

\section{B. Pembahasan}

Media pembelajaran berbasis website (wordwall) mata pelajaran fiqih yang dikembangkan ini telah mengalami proses telaah dari ahli materi dan ahli bahasa, validasi, dan uji terbatas pada siswa. Berdasarkan saran dari penelaah dan validator dan respons siswa, diperoleh media pembelajaran berbasis website (wordwall) mata pelajaran fiqih yang telah layak secara teotitis maupun secara empiris.

Berdasarkan persentase pendapat siswa dari berbagai aspek penilaian diatas menunjukan bahwa siswa memberikan respons positif terhadap media pembelajaran berbasis website (wordwall) mata pelajaran fiqih dikembangkan. Hasil respons siswa, siswa merasa tertarik dengan pembelajaran menggunakan komputer dengan media pembelajaran berbasis website (wordwall) mata pelajaran fiqih yang dikembangkan karena pembelajaran menggunakan computer/HP merupakan pembelajaran yang baru untuk siswa, disamping itu konsep yang diberikan dikaitkan dengan masalah nyata dan bahasa yang mudah dimengerti sehingga siswa merasa tertarik melakukan pembelajaran menggunakan media pembelajaran berbasis website (wordwall) mata pelajaran fiqih pada tema mata. Penyajian materi dan langkah kerja disajikan secara runtut sehingga mempermudah siswa untuk memahami konsep yang disampaikan, selain itu LKS juga dilengkapi fitur-fitur pendukung berupa Gambar dan perpaduan warna yang menarik

Respons positif siswa terhadap media pembelajaran berbasis website (wordwall) mata pelajaran fiqih yang dikembangkan didukung oleh hasil evaluasi yang diberikan kepada siswa. Siswa dievaluasi dengan diberikan 15 soal pilihan ganda dan 5 soal uraian. 2 siswa dari 20 siswa mengalami kesulitan mengerjakan soal dalam game hal tersebut dikarenakan waktu yang singkat sehingga pemantapan materi yang kurang tetapi nilai yang didapat oleh siswa masih melampaui KKM yaitu $\geq 70$.

Nilai yang diperoleh siswa dari hasil evaluasi secara ketuntasan individu mencapai persentase $100 \%$ dan secara klasikal sebesar $100 \%$ sehingga mendukung kelayakan website (wordwall)yang dikembangkan dalam komponen materi point 1 yaitu membantu siswa dalam memahami konsep yang diajarkan.

\section{Kesimpulan}




\section{Idzi’ Layyinnati}

1. Berdasarkan hasil analisis data penelitian, dapat disimpulkan bahwa Media Media Pembelajaran Berbasis Website (wordwall) Mata Pelajaran Fiqih telah layak digunakan karena mencapai persentase $\geq 61 \%$.

2. Kelayakan website (wordwall)ditinjau berdasarkan penilaian para ahli dinyatakan layak dengan persentase kelayakan materi sebesar $88.88 \%$, penyajian sebesar $88.88 \%$, dan kebahasaan sebesar $85.00 \%$. Dari ketiga komponen kelayakan website (wordwall) dikategorikan sangat layak.

3. Kelayakan website (wordwall)ditinjau berdasarkan respon siswa telah layak digunakan berdasarkan persentase meliputi kriteria website (wordwall)dalam pembelajaran sebesar $93.42 \%$, kriteria penyajian $80.26 \%$, dan kriteria bahasa yang digunakan sebesar $75.43 \%$.

\section{Daftar Pustaka}

Arief Sadiman, dkk. 2012. Media Pendidikan. Jakarta: PT. RajaGrafindo Persada Azhar Arsyad. 2013.Media Pembelajaran, (Jakarta: PT. RajaGrafindo Persada, Asri, Nurul. Selly Feranue. Setia Utari. 2010. Efektifitas Penerapan Pembelajaran Konseptual Interaktif untuk Meningkatkan Prestasi Belajar Siswa. Jakarta: Universitas Indonesia.

Badan Pengembangan dan Pembinaan Bahasa Kementrian Pendidikan dan Kebudayaan

Republik $\quad$ Indonesia. $2016 . \quad$ KBBI Daring. (https://kbbi.kemendikbud.go.id/entri/Pengaruh, diakses 9 Februari 2021)

Bambang Warsita. 2008. Teknologi Pembelajaran, Landasan dan Aplikasinya. Jakarta: PT. Rineka Cipta

Fogarty.1991.The Mindfull school: How to integrate the curricula Illinois: IRI/ Skylight Publishing,inch

Hamalik, Oemar. 2005. Metode Belajar dan kesulitan-Kesulitan Belajar. Bandung: Tarsito

Himmatul Husniyah. 2021. Pengaruh Profesionalisme Guru Terhadap Peningkatan Prestasi Belajar Siswa Kelas X Di Madrasah Aliyah 02 Pondok Modern Paciran Lamongan. Jurnal Annaba STIT Muhammadiyah Paciran. Vol. 4 No. 1

Heinich, Robert; Russel, James D; dan Molenda, Michael. 1996. Instructional Media and Technologies for Learning. Colombus: Prentice Hall, inc 
Hergenhahn B.R; Alson Matthew H. 2009. Theories of Learning. Jakarta: Kencana Prenada Media Grup

Idzi' Layyinnati. 2018. Pengaruh Penerapan Media Benda Asli Pada Mata Pelajaran Matematika Terhadap Hasil Belajar Siswa Kelas 1 Di Madrasah Ibtidaiyah. Jurnal Annaba STIT Muhammadiyah Paciran. Vol. 7 No. 2

Idzi' Layyinnati. 2021. Pengaruh Penggunaan Media Gambar Untuk Meningkatkan Hasil Belajar Bahasa Arab Siswa Kelas VII Di Madrasah Tsanawiyah 12 Palirangan. Jurnal Annaba STIT Muhammadiyah Paciran. Vol. 7 No. 1

Maftuhah. 2021. Pengaruh Metode Tanya Jawab Terhadap Prestasi Belajar Siswa Mata Pelajaran Akidah Akhlak Kelas IV Di Madrasah Ibtidaiyah Muhammadiyah 06 Brondong Lamongan. Jurnal Annaba STIT Muhammadiyah Paciran. Vol. 7 No. 1

Mariana. 2019. Peningkatan Pembelajaran PPKN Materi Persiapan Kemerdekaan Indonesia Melalui Pendekatan Contextual Teaching and Learning (CTL) Pada Siswa Kelas VI SD Negeri Muka Bilang. Sains Riset 9

M. Chotibuddin. 2021. Pengaruh Metode Cooperative Type Jigsaw Terhadap Peningkatan Hasil Belajar Siswa Mata Pelajaran Pendidikan Agama Islam Di Kelas VI Madrasah Ibtidaiyah Muhammadiyah 09 Kranji Lamongan. Jurnal Annaba STIT Muhammadiyah Paciran. Vol. 7 No. 1

M. Chotibuddin. 2017. Penggunaan Metode Inkuiri Dalam Peningkatan Hasil Belajar Bahasa Inggris Di Kelas VII Madrasah Tsanawiyah Muhammadiyah 17 Paciran. Jurnal Annaba STIT Muhammadiyah Paciran. Vol. 3 No. 2

Nunuk Suryani, Achmad Setiawan, dan Aditin Putria. 2018. Media Pembelajaran Inovatif dan Pengembangannya. Bandung: PT Remaja Rosdakarya

Riduwan. 2010. Skala Pengukuran Variabel-variabel Penelitian. Bandung: Alfabeta

Rubhan Masykur, Nofrizal, Muhamad Syazali. 2017. Pengembangan Media Pembelajaran Matematika dengan Macromedia Flash. Jurnal Pendidikan Matematika, Vol. 8, No. 2,

Rusman, Deni Kurniawan dan Cepi Riyana 2013. Pembelajaran Berbasis Teknologi Informasi dan Komunikasi. Jakarta: RajaGrafindo Persada

Subhan Adi Santoso. 2020. Media Pembelajaran Pendidikan Agama Islam Era Industri 4.0. Yogyakarta: Deepublish 


\section{Idzi' Layyinnati}

Subhan Adi Santoso. M. Chotibuddin, 2020. Pembelajaran Blended Learning Masa Pandemi. Pasuruan: Qiara Media

Subhan Adi Santoso. Himmatul Husniyah, 2021. Pendidikan Agama Islam Berbasis IT. Yogyakarta: Zahir Publishing

Sidi Gazalba. 1975. Asas Agama Islam. Bulan Bintang, Jakarta

Sukmadinata, Nana S. 2009. Metode Penelitian Pendidikan. Bandung: PT Remaja Rosda Karya

Thiagrajan, S; Semmel, D. S. Semmel, I.M. 1974. Instrucrion Devolopment For Training Teacher Of Ex3eptional Children. Indiana: Indiana Univercity.

Irham Halik, Membuat Games Edukasi dengan Wordwall (https://irhamhalik.com/membuat-games-edukasi-dengan-word-wall/ diakses pada 24 Maret 2021 pukul 23.30 